\title{
Antibacterial, Mutagenic Properties and Chemical Characterisation of Sugar Bush (Protea caffra Meisn.): A South African Native Shrub Species
}

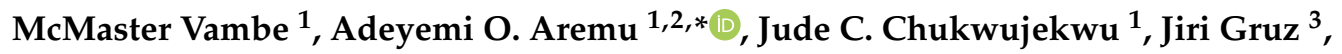 \\ Andrea Luterová ${ }^{3}{ }^{\circledR}$, Jeffrey F. Finnie ${ }^{1}$ and Johannes Van Staden ${ }^{1, *}$ \\ 1 Research Centre for Plant Growth and Development, School of Life Sciences, University of KwaZulu-Natal, \\ Pietermaritzburg, Private Bag X01, Scottsville 3209, South Africa; Vambem@ukzn.ac.za (M.V.); \\ Chukwujekwu@ukzn.ac.za (J.C.C.); Finnie@ukzn.ac.za (J.F.F.) \\ 2 Indigenous Knowledge Systems Centre, Faculty of Natural and Agricultural Sciences, North-West \\ University, Private Bag X2046, Mmabatho 2745, South Africa \\ 3 Laboratory of Growth Regulators, The Czech Academy of Sciences, Institute of Experimental Botany and \\ Palacký University, Šlechtitelů 27, CZ-78371 Olomouc, Czech Republic; jiri.gruz@upol.cz (J.G.); \\ andrea.luterova@upol.cz (A.L.) \\ * Correspondence: Oladapo.Aremu@nwu.ac.za (A.O.A.); rcpgd@ukzn.ac.za (J.V.S.); \\ Tel.: +27-18-389-2573 (A.O.A.); +27-33-2605130 (J.V.S.)
}

Received: 14 August 2020; Accepted: 29 September 2020; Published: 9 October 2020

check for updates

\begin{abstract}
Protea caffra is used as a diarrhoeal remedy in South African herbal medicine, however, its pharmacological properties remain largely unknown. In the present study, extracts from different Protea caffra organs were screened against drug-sensitive and -resistant diarrhoeagenic pathogens using the microdilution assay (minimum inhibitory concentration, MIC). Twig extracts ( $70 \%$ methanol, $\mathrm{MeOH}$ ) of the plant were purified and the resultant fractions screened for antibacterial properties (MIC). The chemical profiles of the fractions were determined by Gas Chromatography-Mass Spectrometry (GC-MS), while ultra-high-performance liquid chromatography-tandem mass spectrometry (UHPLC-MS/MS) was used to quantify the phenolic acids in the plant. The mutagenic properties of bioactive extracts were assessed using the Ames test. The extracts demonstrated weak-moderate antibacterial properties (MIC: $0.3-0.6 \mathrm{mg} / \mathrm{mL}$ ). A cold ethyl acetate fraction of $\mathrm{MeOH}$ twig extract exhibited significant antibacterial properties $(\mathrm{MIC}=0.078 \mathrm{mg} / \mathrm{mL}$ ) against Enterococcus faecalis. The presence of antibacterial compounds (1-adamantane carboxylic acid, heptacosanol, levoglucosan, nonadecanol) in the plant was putatively confirmed based on GC-MS analysis. Furthermore, UHPLC-MS/MS analysis revealed varying concentrations of phenolic acids $(0.08-374.55 \mu \mathrm{g} / \mathrm{g} \mathrm{DW})$. Based on the Ames test, the extracts were non-mutagenic thereby suggesting their safety. To a certain degree, the current study supports the traditional use of Protea caffra to manage diarrhoea among local communities in South Africa.
\end{abstract}

Keywords: antimicrobial; drug-resistance; diarrhoea; GC-MS; mutagenicity; Proteaceae; UHPLC-MS/MS

\section{Introduction}

Diarrhoea is an intestinal disorder characterised by the passage of frequent loose or watery stools in a period of $24 \mathrm{~h} \mathrm{[1].} \mathrm{Infectious} \mathrm{diarrhoea} \mathrm{remains} \mathrm{one} \mathrm{of} \mathrm{the} \mathrm{leading} \mathrm{causes} \mathrm{of} \mathrm{child} \mathrm{mortality}$ worldwide. In 2015 alone, diarrhoeal diseases caused an estimated 1.3 million deaths worldwide and were the fourth leading causes of death among children under the age of 5 years [2]. Some of the prominent etiological agents of community and hospital-aquired diarrhoea include Escherichia coli, Enterococcus faecalis, Klebsiella pneumonia and Staphylococcus aureus [3,4]. Globally, medicinal plants 
are used to manage diarrhoeal symptoms [5]. Acacia nilotica (seed powder), Bacopa monnieri (leaf decoction), Rheum palmatum (rhizome infusions), Santalum album (rhizome infusion) are, for instance, listed in the Asian Pharmacopeia as traditional herbs with anti-diarrhoeal properties [6-8]. In Europe, diarrhoea is managed traditionally using plants such as Matricaria chamonilla (dry flowering decoctions), Solanum tuberosum (tuber decoctions) and Vaccinium myrtillus (fruit decoctions) [9]. African herbs commonly used to treat the disease include Elephantorrhiza elephantina (root decoctions), Euphorbia hirta (leaf macerate), Heinsia pulchella (root bark decoction), Ozoroa insignis (bark decoctions), Psidium guajava (leaf infusions), Sclerocarya birrea (leaf and bark infusions), Solanum supinum (root decoction), Terminalia sericea (root infusions) and Ximenia caffra (roof decoctions) [10-13]. In South Africa, Protea caffra Meisn (Proteaceae) is among the common plants utilised by local herbalists for treating diarrhoea [14].

Protea caffra is a dicotyledonous shrub $(3 \mathrm{~m})$ that grows in different parts of Mozambique, South Africa and Zimbabwe [15-17]. The plant is native to South Africa where it is locally known as the common sugarbush, Natal sugarbush (English), gewone suikerbos, waboom (Afrikaans), isadlunge, indlunge, isiqwanwe (Isixhosa), uhlinkihane (isiZulu), tshididiri, tshidzungu (TshiVhenda), mahlako, mogalagala, segwapi, sekila and tshidzungu (Sotho) [18-20]. As applicable with other members of the genus Protea, it has characteristic large beautiful flower heads which have made it an important ornamental plant in southern Africa and other parts of the world [17]. Apart from having important horticultural purposes, Protea caffra has several ethnomedicinal applications. For instance, the aqueous infusions of the root and stem barkare used to manage bleeding stomach ulcers, diarrhoea or as enemas [14,20]. According to Zukulu [21], the roots of the plant are used to prepare umhlabelo, a decoction used to help heal broken bones. The fruit and stem bark are also used to manage dizziness, while decoctions of dried seeds are used to manage different psychological disorders [22]. A study by Semenya et al. [23], revealed that the Bapedi traditional healers of South Africa use Protea caffra seed infusions to manage chlamydia, a sexually transmitted bacterial infection. However, the scientific basis for the majority of its traditional uses are currently lacking or limited. In addition, the phytochemical and toxicological evaluations of Protea caffra remain pertinent to contribute toward its wider acceptance. The present study investigated the antibacterial (against drug-sensitive and -resistant strains), mutagenic and phytochemical properties of different parts of Protea caffra.

\section{Results}

The antibacterial MIC values of evaluated plant extracts are presented in Table 1 . The extracts were classified as having significant $(\mathrm{MIC} \leq 0.1 \mathrm{mg} / \mathrm{mL})$, moderate $(0.1<\mathrm{MIC} \leq 0.625 \mathrm{mg} / \mathrm{mL})$ or weak (MIC $>0.625 \mathrm{mg} / \mathrm{mL}$ ) antibacterial properties [24]. All aqueous extracts yielded MIC values $>2.5 \mathrm{mg} / \mathrm{mL}$ (Table S1). Generally, the evaluated plant parts demonstrated moderate antibacterial properties with $\mathrm{MIC}$ values ranging from $0.3-0.6 \mathrm{mg} / \mathrm{mL}$. Interestingly, extracts from the seed $(\mathrm{MeOH}$ and petroleum ether) and twigs $(\mathrm{MeOH})$ demonstrated noteworthy antibacterial activities against Gram-negative bacterial strains (Escherichia coli and Klebsiella pneumonia). It was also worth noting that the methanolic leaf and twig extracts of the plant demonstrated promising bacteriostatic properties $(\mathrm{MIC}=0.63 \mathrm{mg} / \mathrm{mL}$ ) against the penicillin-resistant Staphylococcus aureus. However, the other drug-resistant bacterial strains were not susceptible to the plant extracts (MIC $>2.5 \mathrm{mg} / \mathrm{mL}$ ) and hence were excluded from Table 1.

The $\mathrm{MeOH}$ twig extract demonstrated extended-spectrum antibacterial properties (Table 1), an observation that stimulated interest in determining its phytochemical profile. Acetone, cold ethyl acetate and hot ethyl acetate were used to partition the compounds in the biologically active extract and the resultant fractions were screened for antibacterial properties [25]. As shown in Table 2, the acetone and methanol sub-fractions demonstrated very weak antibacterial properties (MIC $\geq 2.5 \mathrm{mg} / \mathrm{mL}$ ). The best antibacterial property was however, exhibited by the cold ethyl acetate sub-fraction which was active against both Gram-negative (Escherichia coli, Klebsiella pneumoniae) and Gram-positive (Enterococcus faecalis, Staphylococcus aureus) bacterial strains (MIC range: $0.078-0.6 \mathrm{mg} / \mathrm{mL}$ ). The hot ethyl acetate sub-fraction demonstrated moderate activities against Enterococcus faecalis $(0.3 \mathrm{mg} / \mathrm{mL})$ and 
Staphylococcus aureus $(0.6 \mathrm{mg} / \mathrm{mL})$. However, none of the fractions evaluated demonstrated noteworthy antibacterial activities against drug-resistant bacterial strains (Table 2).

Table 1. Minimum inhibitory concentration values (MIC, $\mathrm{mg} / \mathrm{mL}$ ) of Protea caffra extracts screened against drug-sensitive and -resistant bacterial strains.

\begin{tabular}{|c|c|c|c|c|c|c|c|c|c|c|c|c|c|}
\hline \multicolumn{14}{|c|}{ Minimum Inhibitory Concentration (MIC, mg/mL) } \\
\hline \multirow[b]{2}{*}{ Plant Part } & \multicolumn{5}{|c|}{ Methanol } & \multicolumn{4}{|c|}{ Dichloromethane } & \multicolumn{4}{|c|}{ Petroleum Ether } \\
\hline & $E c$ & $E f$ & $K p$ & $S a$ & $S a \mathrm{D}$ & $E c$ & $E f$ & $K p$ & $S a$ & $E c$ & $E f$ & $K p$ & $S a$ \\
\hline Bark & 1.25 & 0.63 & $>2.5$ & 0.31 & $>2.5$ & 1.25 & $>2.5$ & 2.5 & 1.25 & 1.25 & $>2.5$ & 2.5 & 1.25 \\
\hline Flowers & 1.25 & 1.25 & 1.25 & 2.5 & 2.5 & 1.25 & 0.63 & 1.25 & 0.63 & 1.25 & 0.63 & 1.25 & 0.63 \\
\hline Leaves & 2.5 & 0.63 & 1.25 & 1.25 & 0.63 & 2.5 & $>2.5$ & 1.25 & 2.5 & 2.5 & $>2.5$ & 1.25 & 2.5 \\
\hline Seeds & 0.63 & 1.25 & 0.31 & 1.25 & 1.25 & 0.63 & 0.63 & 0.31 & 1.25 & 0.63 & 0.63 & 0.31 & 1.25 \\
\hline Twigs & 0.63 & 0.31 & 0.63 & 0.31 & 0.63 & 2.5 & 2.5 & 2.5 & 2.5 & 2.5 & 2.5 & 2.5 & 2.5 \\
\hline Neomycin a $(\mu \mathrm{g} / \mathrm{mL})$ & 0.78 & 0.39 & 1.6 & 0.65 & 6.25 & & & & & & & & \\
\hline
\end{tabular}

Table 2. Minimum inhibitory concentration $(\mathrm{MIC}, \mathrm{mg} / \mathrm{mL}$ ) values of fractions obtained from a methanol extract of Protea caffra twigs.

\begin{tabular}{|c|c|c|c|c|c|c|c|}
\hline \multirow[b]{2}{*}{ Fraction } & \multicolumn{7}{|c|}{ Minimum Inhibitory Concentration (MIC, mg/mL) } \\
\hline & $E c$ & $E c \mathrm{D}$ & $E f$ & $K p$ & $K p \mathrm{D}$ & $S a$ & $S a \mathrm{D}$ \\
\hline Acetone & $>2.5$ & $>2.5$ & $>2.5$ & $>2.5$ & $>2.5$ & 1.25 & $>2.5$ \\
\hline Cold ethyl acetate & 0.6 & $>2.5$ & 0.078 & 0.3 & $>2.5$ & 0.15 & $>2.5$ \\
\hline Hot ethyl acetate & $>2.5$ & $>2.5$ & 0.3 & $>2.5$ & $>2.5$ & 0.6 & $>2.5$ \\
\hline $\mathrm{MeOH}$ & $>2.5$ & $>2.5$ & $>2.5$ & $>2.5$ & $>2.5$ & $>2.5$ & $>2.5$ \\
\hline Neomycin ${ }^{a}(\mu \mathrm{g} / \mathrm{mL})$ & 0.78 & 6.4 & 0.39 & 1.6 & 8.3 & 0.65 & 6.3 \\
\hline
\end{tabular}

a = positive control, Ec D = Multidrug-resistant Escherichia coli, Ef = Enterococcus faecalis, Kp = Klebsiella pneumoniae, $\mathrm{Kp} \mathrm{D}=$ Multidrug-resistant Klebsiella pneumoniae, Sa = Staphylococcus aureus, Sa D = Penicillin-resistant Staphylococcus aureus, $\mathrm{MeOH}=$ Methanol. ${ }^{*}$ Values in bold are considered noteworthy antibacterial activity.

GC-MS data analysis revealed that the aqueous (70\%) MeOH extract of Protea caffra twigs consisted of 15 compounds (Table 3, Figures S1-S3). No peaks were obtained from the methanol sub-fraction. The major phytocompounds in the cold ethyl acetate sub-fraction were polygalitol (34.76\%), phenol, 4-(1,1,3,3-tetramethylbutyl) (9.8\%), Spiro-1-(cyclohex-2-ene)-2'-(5'-oxabicyclol) (8.2\%), 1-adamantane carboxylic acid $(8.07 \%)$ and carbamic acid $(7.03 \%)$, which together accounted for approximately $60 \%$ of the compounds found in the sub-fraction (Table 3). The hot ethyl acetate sub-fraction consisted of 1-heptacosanol (70.57\%) as its major component (Table 3). Oxalyl chloride (51.12\%) and polygalitol $(48.88 \%)$ were the only compounds detected in the acetone sub-fraction.

The UHPLC-MS/MS analysis revealed that Protea caffra contained varying quantities of both hydroxybenzoic and hydroxycinnamic acids (Tables 4 and 5). Overall, the most abundant hydroxybenzoic ( $p$-hydroxybenzoic acid, $374.55 \mu \mathrm{g} / \mathrm{g} \mathrm{DW}$ ) and hydroxycinnamic (caffeic acid, $266.37 \mu \mathrm{g} / \mathrm{g} \mathrm{DW}$ ) acids were detected in the leaves. The leaves also contained the least abundant hydroxycinnamic acids (sinapic acid, $0.08 \mu \mathrm{g} / \mathrm{g}$ DW), while the bark contained the least abundant hydroxybenzoic acid (salicylic acid, $0.1 \mu \mathrm{g} / \mathrm{g}$ DW). 
Table 3. Gas Chromatograph-Mass Spectroscopy (GC-MS) data of phytocompounds putatively identified in different sub-fractions of methanolic extracts of Protea caffra twigs.

\begin{tabular}{|c|c|c|c|c|c|c|}
\hline Sub-Fraction & Chemical Name & Retention Time & Area \% & Similarity \% & Molecular Formulae & Molecular Weight \\
\hline \multirow[t]{13}{*}{ Cold ethyl acetate } & Polygalitol & 13.35 & 34.76 & 95 & $\mathrm{C}_{6} \mathrm{H}_{12} \mathrm{O}_{5}$ & 164 \\
\hline & Phenol, 4-(1,1,3,3-tetramethylbutyl)- & 15.38 & 9.8 & 89 & $\mathrm{C}_{14} \mathrm{H}_{22} \mathrm{O}$ & 206 \\
\hline & Spiro-1-(cyclohex-2-ene)-2'-(5'-oxabicyclol) & 14.94 & 8.2 & 77 & $\mathrm{C}_{14} \mathrm{H}_{22} \mathrm{O}$ & 206 \\
\hline & 1-Adamantanecarboxylic acid, 2-propenyl & 15.03 & 8.07 & 89 & $\mathrm{C}_{14} \mathrm{H}_{20} \mathrm{O}_{2}$ & 220 \\
\hline & $\begin{array}{l}\text { Carbamic acid, } \\
\text { N-[1,1-bis(trifluoromethyl)ethyl }\end{array}$ & 14.85 & 7.03 & 90 & $\mathrm{C}_{19} \mathrm{H}_{25} \mathrm{~F}_{6} \mathrm{NO}_{2}$ & 413 \\
\hline & Phenol, 2-methyl-4-(1,1,3,3-tetramethylbutyl)- & 15.27 & 6.23 & 80 & $\mathrm{C}_{15} \mathrm{H}_{24} \mathrm{O}$ & 220 \\
\hline & Hexestrol, O-acetyl- & 15.16 & 3.57 & 88 & $\mathrm{C}_{20} \mathrm{H}_{24} \mathrm{O}_{3}$ & 312 \\
\hline & 1-Heptacosanol & 19.41 & 2.86 & 94 & $\mathrm{C}_{27} \mathrm{H}_{56} \mathrm{O}$ & 396 \\
\hline & 1,2-Bis(p-acetoxyphenyl)ethanedione & 14.74 & 2.1 & 77 & $\mathrm{C}_{18} \mathrm{H}_{14} \mathrm{O}_{6}$ & 326 \\
\hline & 1,3-Benzenediol, 4-propyl- & 13.73 & 1.83 & 83 & $\mathrm{C}_{9} \mathrm{H}_{12} \mathrm{O}_{2}$ & 152 \\
\hline & Phthalic acid, butyl tridecyl ester & 18.53 & 1.74 & 75 & $\mathrm{C}_{22} \mathrm{H}_{28} \mathrm{O}_{4}$ & 356 \\
\hline & 1-Nonadecanol & 15.89 & 1.60 & 93 & $\mathrm{C}_{19} \mathrm{H}_{40} \mathrm{O}$ & 284 \\
\hline & Phenol 2,4-bis (1,1-dimethylethyl) & 12.84 & 1.16 & 94 & $\mathrm{C}_{14} \mathrm{H}_{22} \mathrm{O}$ & 206 \\
\hline \multirow[t]{6}{*}{ Hot ethyl acetate } & 1-Heptacosanol & 14.16 & 70.57 & 90 & $\mathrm{C}_{27} \mathrm{H}_{56} \mathrm{O}$ & 396 \\
\hline & 1,3,5-Benzenetriol & 13.55 & 15.42 & 95 & $\mathrm{C}_{6} \mathrm{H}_{6} \mathrm{O}_{3}$ & 126 \\
\hline & Polygalitol & 12.99 & 7.31 & 72 & $\mathrm{C}_{6} \mathrm{H}_{12} \mathrm{O}_{5}$ & 164 \\
\hline & 1,3-Benzenediol, 4-propyl- & 13.73 & 3.93 & 70 & $\mathrm{C}_{9} \mathrm{H}_{12} \mathrm{O}_{2}$ & 152 \\
\hline & B-Glucopyranose, 1,6-anhydro-(levoglucosan) & 11.60 & 2.78 & 70 & $\mathrm{C}_{6} \mathrm{H}_{10} \mathrm{O}_{5}$ & 162 \\
\hline & 1-Nonadecanol & 15.89 & 1.6 & 93 & $\mathrm{C}_{19} \mathrm{H}_{40} \mathrm{O}$ & 284 \\
\hline \multirow[t]{2}{*}{ Acetone } & Oxalyl acid & 3.23 & 51.12 & 93 & $\mathrm{C}_{2} \mathrm{C}_{\mathrm{I} 2} \mathrm{O}_{2}$ & 126 \\
\hline & Polygalitol & 13.22 & 48.88 & 95 & $\mathrm{C}_{6} \mathrm{H}_{12} \mathrm{O}_{5}$ & 164 \\
\hline
\end{tabular}


Table 4. Quantity ( $\mu \mathrm{g} / \mathrm{g} \mathrm{DW}$ ) of hydroxybenzoic acids in $80 \%$ methanol Protea caffra extracts. Values represent mean \pm standard error, $n=3$.

\begin{tabular}{|c|c|c|c|c|c|c|c|}
\hline \multicolumn{8}{|c|}{ Hydroxybenzoic Acids ( $\mu \mathrm{g} / \mathrm{g}$ DW) } \\
\hline Plant Part & Catechin Acid & Gallic Acid & $\begin{array}{l}p \text {-Hydroxybenzoic } \\
\text { Acid }\end{array}$ & $\begin{array}{c}p \text {-Protocatechuic } \\
\text { Acid }\end{array}$ & Salicylic Acid & Syringic Acid & Vanillic Acid \\
\hline Bark & $6.83 \pm 1.4^{c}$ & $0.3 \pm 0.3^{b}$ & $1.95 \pm 0.1^{\mathrm{d}}$ & $88.1 \pm 4.4^{b}$ & $0.1 \pm 0^{\mathrm{e}}$ & $2.4 \pm 0.4^{\mathrm{a}}$ & $4.7 \pm 0.2^{c}$ \\
\hline Leaves & $17.98 \pm 0.51^{\mathrm{a}}$ & $1.50 \pm 0.03^{a}$ & $374.55 \pm 9.14^{\mathrm{a}}$ & $184.35 \pm 4.44^{\mathrm{a}}$ & $5.07 \pm 0.08^{b}$ & $1.22 \pm 0.02^{c}$ & $23.35 \pm 0.13^{\mathrm{a}}$ \\
\hline Seeds & $<\mathrm{LOD}$ & $0.69 \pm 0.23^{b}$ & $23.74 \pm 0.37^{c}$ & $44.22 \pm 1.32 \mathrm{~d}$ & $1.55 \pm 0.04^{\mathrm{d}}$ & $0.67 \pm 0.03^{d}$ & $4.8 \pm 90.2^{c}$ \\
\hline Twigs & $13.02 \pm 2.03^{b}$ & $0.42 \pm 0.02^{b}$ & $4.94 \pm 0.36^{\mathrm{d}}$ & $17.65 \pm 0.76^{\mathrm{e}}$ & $1.85 \pm 0.03^{c}$ & $1.28 \pm 0.3^{c}$ & $6.66 \pm 0.09^{c}$ \\
\hline Flowers & $4.08 \pm 1.3^{\mathrm{d}}$ & $1.63 \pm 0.04^{\mathrm{a}}$ & $156.87 \pm 5.03^{b}$ & $50.35 \pm 1.57^{c}$ & $7.73 \pm 0.36^{\mathrm{a}}$ & $1.58 \pm 0.07^{b, c}$ & $10.86 \pm 0.7^{b}$ \\
\hline
\end{tabular}

In each column, values with different letters are significantly different $(p \leq 0.05)$ as separated by Duncan's Multiple Range Test.

Table 5. Quantity ( $\mu \mathrm{g} / \mathrm{g}$ DW) of hydroxycinnamic acids in $80 \%$ methanol Protea caffra extracts. Values represent mean \pm standard error, $n=3$.

\begin{tabular}{cccccc}
\hline \multicolumn{5}{c}{ Hydroxycinnamic Acids $(\mu \mathrm{g} / \mathrm{g} \mathrm{DW})$} \\
\hline Plant Part & Caffeic Acid & Chlorogenic Acid & $p$-Coumaric Acid & Ferulic Acid & Sinapic Acid \\
\hline Bark & $5.69 \pm 0.22^{\mathrm{e}}$ & $0.56 \pm 0.03^{\mathrm{d}}$ & $1.69 \pm 0.06^{\mathrm{d}}$ & $14.12 \pm 0.39^{\mathrm{a}}$ & $0.2 \pm 0^{\mathrm{b}}$ \\
Leaves & $266.37 \pm 1.46^{\mathrm{a}}$ & $11.67 \pm 0.28^{\mathrm{b}}$ & $21.22 \pm 0.54^{\mathrm{a}}$ & $2.68 \pm 0.18^{\mathrm{e}}$ & $0.08 \pm 00^{\mathrm{c}}$ \\
Seeds & $29.09 \pm 0.77^{\mathrm{c}}$ & $3.34 \pm 0.16^{\mathrm{c}}$ & $10.03 \pm 0.4^{\mathrm{b}}$ & $4.89 \pm 0.2^{\mathrm{d}}$ & $0.09 \pm 0.01^{\mathrm{c}}$ \\
Twigs & $9.36 \pm 0.39^{\mathrm{d}}$ & $29.91 \pm 1.21^{\mathrm{a}}$ & $5.3 \pm 0.26^{\mathrm{c}}$ & $5.68 \pm 0.26^{\mathrm{c}}$ & $0.23 \pm 0.13^{\mathrm{a}}$ \\
Flowers & $39.36 \pm 1.39^{\mathrm{b}}$ & $4.82 \pm 0.2^{\mathrm{c}}$ & $10.77 \pm 0.62^{\mathrm{b}}$ & $6.92 \pm 0.13^{\mathrm{b}}$ & $0.24 \pm 0.03^{\mathrm{a}}$ \\
\hline
\end{tabular}

In each column, values with different letters are significantly different $(p \leq 0.05)$ as separated by Duncan's Multiple Range Test.

None of the evaluated plant extracts demonstrated concentration-dependent increase in the number of $\mathrm{His}^{+}$revertants (Table 6). The average TA98 revertants ranged from 6.4-29.0, while the TA102 revertants ranged from 109.7-284.3. The corresponding average number of TA98 and TA102 revertants in the negative control were 19.1 and 145.2, respectively. The evaluated extracts were therefore non-mutagenic against TA98 and TA102 tester strains [26].

Table 6. Number of $\mathrm{His}^{+}$revertants in Salmonella typhimurium strains TA98 and TA102 produced by Protea caffra organic solvent extracts.

\begin{tabular}{|c|c|c|c|c|c|c|c|}
\hline \multirow[b]{3}{*}{ Plant organ } & \multicolumn{7}{|c|}{ Number of $\mathrm{His}^{+}$Revertants/Plate (mg/mL) } \\
\hline & \multirow[b]{2}{*}{ Solvent } & \multicolumn{3}{|c|}{ TA98 } & \multicolumn{3}{|c|}{ TA102 } \\
\hline & & 5 & 0.5 & 0.05 & 5 & 0.5 & 0.05 \\
\hline \multirow[t]{2}{*}{ Bark } & $\mathrm{MeOH}$ & $9.7 \pm 2.3$ & $8.3 \pm 3.2$ & $10.7 \pm 1.5$ & $248.0 \pm 20.1$ & $174.7 \pm 11.7$ & $177.3 \pm 15.5$ \\
\hline & PE & $6.4 \pm 2.1$ & $19.8 \pm 4.1$ & $15.8 \pm 6.1$ & $213.5 \pm 15.9$ & $172.5 \pm 26.2$ & $245.6 \pm 21.1$ \\
\hline Flowers & PE & $13.6 \pm 5.2$ & $8.8 \pm 2.6$ & $12.6 \pm 3.2$ & $228.0 \pm 12.1$ & $145.3 \pm 22.5$ & $207.0 \pm 12.8$ \\
\hline Seeds & PE & $8.7 \pm 3.2$ & $11.6 \pm 1.9$ & $21.9 \pm 7.6$ & $269.0 \pm 33.6$ & $276.0 \pm 18.2$ & $208.0 \pm 25.6$ \\
\hline Twigs & $\mathrm{MeOH}$ & $22.0 \pm 6.2$ & $29.0 \pm 8.2$ & $17.3 \pm 6.7$ & $192.0 \pm 6.2$ & $235.0 \pm 22.5$ & $284.3 \pm 27.4$ \\
\hline \multirow[t]{3}{*}{ Leaves } & $\mathrm{MeOH}$ & $16.7 \pm 1.5$ & $15.7 \pm 11.0$ & $27.0 \pm 11.4$ & $278.0 \pm 30.2$ & $109.7 \pm 22.0$ & $281.0 \pm 43.9$ \\
\hline & PE & $7.2 \pm 2.3$ & $22.8 \pm 7.6$ & $19.5 \pm 4.9$ & $233.6 \pm 16.5$ & $246.0 \pm 17.7$ & $217.6 \pm 14.7$ \\
\hline & $\begin{array}{r}\text { Water (-ve } \\
\text { control) }\end{array}$ & & $19.1 \pm 8.4$ & & & $145.2 \pm 17$ & \\
\hline
\end{tabular}

The data presented are the mean \pm standard error of six plates from two separate experiments each performed in triplicate. $\mathrm{DCM}=$ Dichloromethane, $\mathrm{MeOH}=$ Methanol, $\mathrm{PE}=$ Petroleum ether, $-\mathrm{ve}=$ negative + ve = positive control.

\section{Discussion}

Given that water is one of the most commonly used solvent in folklore medicine [27], it was included in the present study to mimic traditionally prepared herbal medicines. However, water extracts have been widely reported to exhibit poor antibacterial activity. This is attributed to the 
fact that many antibacterial phyto-compounds are non-polar or have intermediate polarity and as such cannot be readily extracted from plant material using water [28,29]. In the current study, it is possible that the antibacterial compounds in Protea caffra water extracts occurred in very low, sub-lethal concentrations resulting in poor antibacterial activity (Table S1). It should, however, be noted that some phyto-compounds indirectly help patients fend off pathogenic infections by acting as immune boosters [30]. Furthermore, some of the bioactive compounds in water extracts may exist as pro-drugs, which only become bactericidal once they are modified in the human body [27]. The presence of immune stimulators and pro-drugs in plant extracts cannot be detected using the techniques employed in the current study, as such, further studies are warranted to determine the chemical profiles of traditionally prepared herbal medicines.

The current study revealed for the first time that Protea caffra has potent and extended-spectrum antibacterial properties, which could be attributed to a wide range of biologically active compounds present in the plant. The twigs, for instance, contained 8 putative antibacterial compounds (caffeic, $p$-coumaric, gallic, ferulic chlorogenic acids, adamantyl heterocycle, heptacosanol and nonadecanol, Tables 3-5) and they demonstrated moderate antibacterial properties against the majority of the evaluated bacterial strains (Table 1). In particular, they also exhibited significant antibacterial activities against Enterococcus faecalis (MIC $=0.078 \mathrm{mg} / \mathrm{mL}$, Table 2). The antibacterial properties observed in the present study were generally comparable to those previously reported for some South African medicinal plants such as Newtonia hildebrandtii, Newtonia buchanannii, Ozoroa insignis, Syzgium cordatum, Terminalia. sericea, and Trichilia emetica (MIC range: $0.1-0.6 \mathrm{mg} / \mathrm{mL}$ ) [4,12,13,31].

Relatively higher concentrations of caffeic and $p$-coumaric acids ( $>10 \mu \mathrm{g} / \mathrm{g}$ DW) in the seed (Table 5) could have contributed to the inhibitory effects $\mathrm{MeOH}$ seed extracts had on the growth of Escherichia coli, Klebsiella pneumoniae and Staphylococcus aureus (Table 1). The current observations could perhaps explain why some herbalists in South Africa use Protea caffra seeds to manage bacterial infections including chlamydia [32]. The presence of different types of antibacterial compounds in the leaves and twigs could also perhaps justify the observed moderate antibacterial properties these organs had against penicillin-resistant Staphylococcus aureus (Table 1).

The antibacterial compounds present in Protea caffra worked in different synergistic combinations or individually to affect the observed bacteriostatic properties. Different groups of phenolic compounds often exhibit unique antibacterial mechanisms. Gallic and ferulic acids for example, exert their bactericidal effects by binding to and rupturing bacterial cell membranes [33]. Chlorogenic acid on the other hand, binds to bacterial membranes and increases their permeability. This in turn causes the leakage of both cytoplasmic and nuclei material, eventually leading to bacterial cell death [34]. $P$-coumaric acid also causes intracellular material leakages and interferes with bacterial DNA replication and gene expression [35].

Apart from phenolic acids, Protea caffra contained additional antibacterial compounds as revealed by GC-MS analysis. For instance, 1-Adamantyl heterocycle, which was detected in the twigs of Protea caffra, is usually incorporated into anti-infectious molecules to improve their efficacy [36]. Several potent antimicrobial and antiviral agents such as Rimantadine [37], Oxadiazole [38], Isoxazole [39] and Thiadiazole [40] are all 1-adamantanyl derivatives. It was of great interest to note that Protea caffra produces levoglucosan (Table 3), an important source of C1-C10 and C1-C13 carbon skeletons used to produce the antibiotics erythromycin A and B, [41,42]. 1-Heptacosanol, another compound detected in Protea caffra, is a fatty alcohol present in plants [43], marine algae [44] and cuttlefish, Sepiella inermis [45]. The compound has potent antimicrobial properties [46]. The presence of 1-heptacosanol in Protea caffra suggests that the plant might have potent antioxidant [44,47], nematocidal [48] and antidiabetic [49] properties. Unlike 1-nonadecanol which is a known antibacterial phyto-compound [50], polygalitol has not yet been demonstrated to have antibacterial properties, but has been detected in several plant extracts with potent antibacterial activities [51]. Polygalitol was the most abundant compound in the cold ethyl acetate fraction which demonstrated broad-spectrum antibacterial activities in the present study (Table 2). Further studies are warranted to determine the compound's phytochemical properties. 
Given that 1-heptacosanol, an antibacterial compound, was the major phyto-chemical constituent in the hot ethyl acetate fraction, it is logical to suggest that it was probably the one that inhibited the growth of both Enterococcus faecalis and Staphylococcus aureus (Table 2). Polygalitol and other phyto-compounds detected in this sub-fraction could also have contributed to the observed antibacterial activities. Oxalyl chloride detected in the acetone sub-fraction is a synthetic compound used in oxidative processes involved in manufacturing antibiotics, pesticides, herbicides and other organic products $[52,53]$. There are no indications in the current literature suggesting that the compound is produced by plants and/or that it is biologically active. Oxalyl chloride was therefore probably incorporated into Protea caffra tissues from an external source. Further investigation would reveal which of the two compounds present in the sub-fraction (acetone) was responsible for the weak antibacterial activity observed against $S$. aureus (MIC $\geq 1.25 \mathrm{mg} / \mathrm{mL}$ ). The principle antibacterial compounds in the Protea caffra should, however, be unequivocally identified and their respective antibacterial mechanisms elucidated.

Given that some plants are inherently toxic [54], the safety of traditional herbal remedies remains a serious cause of concern. It was encouraging to note that all evaluated plant extracts were non-mutagenic against both Salmonella typhimurium tester strains (TA98 and TA102, Table 6). Based on accessed literature, none of the plant species within the genus Protea have been reported to have potential toxic effects on humans. It is, however, important to note that while some medicinal plants exhibit non-mutagenic effects in vitro, they may possess cytotoxic effects [55]. It should also be kept in mind that besides mutagenesis, carcinogens can also induce cancerous growth in animals through altering intracellular signals and gene expressions both of which are not detected by the Ames test [56]. It is therefore imperative that further toxicological studies be conducted to ascertain the plant's safety.

\section{Materials and Methods}

\subsection{Plant Material Collection, Sample Preparation and Extraction}

Plant samples were collected, prepared and preserved as previously described [57]. The plant was positively identified by the Curator of the Bews Herbarium [University of KwaZulu-Natal (UKZN), Pietermaritzburg, South Africa] and the voucher specimen (NU0048533) deposited in the UKZN Bews Herbarium.

At a ratio of 10:1 $(10 \mathrm{~mL} / \mathrm{g})$, dry powdered samples were mixed with different solvents (water, methanol $=\mathrm{MeOH}$, dichloromethane $=\mathrm{DCM}$, and petroleum ether $=\mathrm{PE}$ ) and stirred in a rotary shaker (Edmund Bühler, Tübingen, German) for $12 \mathrm{~h}$ at $150 \mathrm{rpm}$ at room temperature, after which they were sonicated for $1 \mathrm{~h}$ on ice (Julabo GMBH, Seelbach, Germany). Organic solvent extracts were filtered using Whatman No. 1 filter paper under vacuum and later concentrated using a rotary evaporator (Heldolph vv 2000, Germany) at $35^{\circ} \mathrm{C}$. Concentrated organic solvent extracts were transferred into glass pill vials and air-dried in front of a fan. All water extracts were freeze-dried. The resultant dried extracts were kept in closed glass pill vials in the dark at $10{ }^{\circ} \mathrm{C}$ until required for further use.

\subsection{Antibacterial Susceptibility Test}

Minimum inhibitory concentration (MIC) values of aqueous and organic solvent extracts obtained from the plant were determined using 96-well microplates (Greiner Bio-one, Germany) as previously described [25]. Dried plant extracts were re-suspended in $2 \%$ dimethylsulfoxide (DSMO, $10 \mathrm{mg} / \mathrm{mL}$ ) after which they were serially diluted (2-fold) with sterile distilled water. Neomycin $(1 \mathrm{mg} / \mathrm{mL})$ was used as a positive control. Sterile distilled water and 2\% DSMO were included as the negative controls for each bacterial strain (Escherichia coli ATCC 11775, Enterococcus faecalis ATCC 19433, Klebsiella pneumoniae ATCC 13883, MDR E. coli ATCC 25218, MDR Klebsiella pneumoniae ATCC 70603, drug-sensitive Staphylococcus aureus ATCC 12600 and penicillin-resistant Staphylococcus aureus ATCC 11632). Diluted overnight cultures were used at a final inoculum of $\approx 5 \times 10^{5} \mathrm{cfu} / \mathrm{mL}$. 


\subsection{Liquid-to-Liquid Fractionation and Gas Chromatography-Mass Spectroscopy (GC-MS)}

Concentrated aqueous (70\%) $\mathrm{MeOH}$ extract of Protea caffra twigs was sequentially extracted with cold ethyl acetate $\left(10^{\circ} \mathrm{C}, 3 \times 50 \mathrm{~mL}\right)$, hot ethyl acetate $\left(50^{\circ} \mathrm{C}, 3 \times 50 \mathrm{~mL}\right)$ and acetone (room temperature, $3 \times 100 \mathrm{~mL}$ ). The resultant fractions were separately concentrated to dryness in vacuo to give four solvent fractions: acetone, cold ethyl acetate, hot ethyl acetate and methanol. The four fractions were screened for antibacterial activities against seven bacterial strains (Enterococcus faecalis, Escherichia coli, MDR Escherichia coli, Klebsiella pneumoniae, MDR Klebsiella pneumoniae, Staphylococcus aureus and penicillin-resistant Staphylococcus aureus) as previously described by Eloff [25].

GC-MS analysis of the four fractions was carried out at the School of Chemical and Physical Sciences, University of KwaZulu-Natal, Pietermaritzburg, South Africa, using a Shimadzu QP-2010 SE Gas Chromatography coupled with (an Agilent) 5973 Mass Selective detector and driven by Agilent Chemstation software. A Zebron ZB-5MSplus capillary column $(30 \mathrm{~m} \times 0.25 \mathrm{~mm}$ internal diameter, $0.25 \mu \mathrm{m}$ film thickness) was used. The carrier gas was ultra-pure helium at a flow rate of $1.0 \mathrm{~mL} / \mathrm{min}$ and a linear velocity of $37 \mathrm{~cm} / \mathrm{s}$. Three microlitres of the sample were injected into the column with the injector temperature set at $250{ }^{\circ} \mathrm{C}$. The initial oven temperature was at $60^{\circ} \mathrm{C}$ which was programmed to increase to $280^{\circ} \mathrm{C}$ at the rate of $10^{\circ} \mathrm{C}$ per min with a hold time of 3 min at each increment. The mass spectrometer was operated in the electron ionization mode at $70 \mathrm{eV}$ and electron multiplier voltage at $1859 \mathrm{~V}$. Other MS operating parameters were as follows: ion source temperature $230^{\circ} \mathrm{C}$, quadrupole temperature $150^{\circ} \mathrm{C}$, solvent delay $4 \mathrm{~min}$ and scan range 50-700 amu. The compounds were identified by direct comparison of the mass spectrum of the analyte at a particular retention time to that of reference standards found in the 2011 National Institute of Standards and Technology (NIST) library. The area percentage of each component was calculated by comparing its average peak area to the total area obtained.

\subsection{Ultra-High Performance Liquid Chromatography-MS/MS (UHPLC) Analysis of Phenolic Acids}

Phenolic acids present in aqueous (80\%) methanol extracts of the different plant parts were identified and quantified using Ultra-high performance liquid chromatography-tandem mass spectrometry (UHPLC-MS/MS) as previously described [58]. The assay was done in triplicate and results presented as mean \pm standard error. The mean values obtained were compared using one-way analysis of variance (ANOVA) and where statistical significance $(p \leq 0.05)$ existed, these values were further separated using the Duncan's multiple range test. Bio-statistical analysis were done using the SPSS version 24.0 for Windows (IBM SPSS Inc., Chicago, IL, USA).

\subsection{Ames Test}

The mutagenic properties of different extracts from the plant were evaluated using the Ames Salmonella/ -Microsome assay involving two Salmonella typhimurium tester strains, TA98 and TA102, in the absence of S9 metabolic activation $[59,60]$. One hundred microliters of sterile distilled water served as the negative control, while $2 \mu \mathrm{g} / \mathrm{plate}$ of $4 \mathrm{NQO}$ were used as the positive control. The assay was conducted twice, and results presented as mean \pm standard error number of reverted colonies per plate. Plant samples that induced a 2-fold increase in the number of $\mathrm{His}^{+}$revertants compared to the negative control were considered to be mutagenic. Additionally, samples that exhibited a dose-dependent increase in the number of $\mathrm{His}^{+}$revertants were classified as mutagenic [26].

\section{Conclusions}

Natural products and their derivatives have, of late, attracted much attention as potential sources of drug leads that could be effective in combating microbial infections prevalent in humans. The present study revealed that Protea caffra is a potential source of antibacterial compounds effective against both drug-sensitive and -resistant bacterial strains. It is, however, pertinent that the antibacterial compounds in the plant be unequivocally identified and their mode of action elucidated. This is the first report on 
the pharmacologically properties of Protea caffra and based on the current findings, it is recommended that the other members of Protea species (>300) be explored for potential therapeutic properties.

Supplementary Materials: The following are available online at http://www.mdpi.com/2223-7747/9/10/1331/s1, Table S1: Minimum inhibitory concentration values (MIC, $\mathrm{mg} / \mathrm{mL}$ ) of aqueous extracts of Protea caffra screened against drug-sensitive and -resistant bacterial strains; Figure S1: GC-MS chromatogram of a cold ethyl acetate sub-fraction obtained from methanolic extracts of Protea caffra twigs. $a=$ Phenol 2,4-bis(1,1-dimethylethyl); $\mathrm{b}=$ Polygalitol; $\mathrm{c}=1,3$-Benzenediol, 4-propyl-; $\mathrm{d}=1$ 1,2-Bis (p-acetoxyphenyl) ethanedione; e = 1-Adamantanecarboxylic acid, 2-propenyl; $\mathrm{f}=$ Phenol, 2-methyl-4-(1,1,3,3-tetramethylbutyl)-; $\mathrm{g}=$ Phenol, 4-(1,1,3,3-tetramethylbutyl)-; $\mathrm{h}$ = Phenol, 2-methyl-4-(1,1,3,3-tetramethylbutyl)-; i = 1-Nonadecanol; $\mathrm{j}=$ Phthalic acid, butyl tridecyl ester; $\mathrm{k}=1$-Heptacosanol; Figure S1.1. Extension of a GC-MS chromatogram (14-16 mins) of a cold ethyl acetate sub-fraction obtained from methanolic extracts of Protea caffra twigs; Figure S2. GC-MS chromatogram of a hot ethyl acetate sub-fraction obtained from methanol extracts of Protea caffra twigs. $a=ß$-Glucopyranose, 1,6-anhydro-, 1,6-anhydro-; $b=$ Polygalitol; $c=1,3,5$-Benzenediol, 4-propyl-; $d=$ 1,3-Benzenediol, 4-propyl-; e = 1-Heptacosanol; Figure S3. GC-MS chromatogram of an acetone sub-fraction obtained from methanolic extracts of Protea caffra twigs. a = Oxalyl acid; $b=$ Polygalitol.

Author Contributions: M.V. conceptualized the project and prepared the manuscript. J.G. and A.L. were involved with the phytochemical analysis, while A.O.A. assisted with the conceptualization, provided technical support and edited the manuscript. J.C.C. assisted with the Ames test. J.F.F. and J.V.S. provided the facilities and supervised the project. All authors have read and agreed to the published version of the manuscript.

Funding: We would like to acknowledge the financial support received from the University of KwaZulu-Natal (UKZN), Pietermaritzburg and the National Research Foundation (NRF: Indigenous Knowledge System grant UID: 93175) Pretoria, South Africa. We would also like to acknowledge the support received from the ERDF (Czech) project "Development of pre-applied research in Nanotechnogy and Biotechnology" (No. CZ.02.1.01/0.0/0.0/17 _048/0007323). The Article Processing Charge was funded by the Faculty of Natural and Agricultural Sciences, North-West University, Mmabatho, South Africa.

Acknowledgments: The authors are also grateful to Alison Young (UKZN Botanical Garden), Christina Potgieter (UKZN Bews Herbarium), Solomon Nenungwi (Walter Sisulu South African National Biodiversity Institute, Johannesburg, South Africa) and Brain Vambe for helping with plant identification and collection.

Conflicts of Interest: We do not have any conflict of interests with respect to this study. The opinions and conclusions/recommendations expressed in this work are that of the authors, and that the funder accepts no liability whatsoever in this regard.

\section{References}

1. WHO; Division of Diarrhoeal and Acute Respiratory Disease Control. The Treatment of Diarrhoea. In $A$ Manual for Physicians and Other Senior Health Workers; World Health Organisation: Geneva, Switzerland, 1990.

2. Wang, H.; Naghavi, M.; Allen, C.; Barber, R.M.; Bhutta, Z.A.; Carter, A.; Casey, D.C.; Charlson, F.J.; Chen, A.Z.; Coates, M.M.; et al. Global, regional, and national life expectancy, all-cause mortality, and cause-specific mortality for 249 causes of death, 1980-2015: A systematic analysis for the Global Burden of Disease Study. Lancet 2016, 388, 1459-1544. [CrossRef]

3. Thi, P.L.N.; Yassibanda, S.; Aidara, A.; Le Bouguénec, C.; Germani, Y. Enteropathogenic Klebsiella pneumoniae HIV-infected adults, Africa. Emerg. Infect. Dis. 2003, 9, 135-137. [CrossRef] [PubMed]

4. Ahmed, A.S.; Elgorashi, E.E.; Moodley, N.; McGaw, L.J.; Naidoo, V.; Eloff, J.N. The antimicrobial, antioxidative, anti-inflammatory activity and cytotoxicity of different fractions of four South African Bauhinia species used traditionally to treat diarrhoea. J. Ethnopharmacol. 2012, 143, 826-839. [CrossRef] [PubMed]

5. Palombo, E.A. Phytochemicals from traditional medicinal plants used in the treatment of diarrhoea: Modes of action and effects on intestinal function. Phytother. Res. 2006, 20, 717-724. [CrossRef] [PubMed]

6. Rout, P.; Panda, T. Ethnobotanical survey of medicinal plants used for the treatment of diarrhoea and dysentery by the tribals of Similipal forest, Mayurbhanj, Odisha, India. Appl. Sci. 2017, 19, 9-18.

7. Liu, C.; Zheng, Y.; Xu, W.; Wang, H.; Lin, N. Rhubarb tannins extract inhibits the expression of aquaporins 2 and 3 in magnesium sulphate-induced diarrhoea model. BioMed Res. Int. 2014, 2014, 1-14. [CrossRef]

8. Guo, H.; Zhang, J.; Gao, W.; Qu, Z.; Liu, C. Anti-diarrhoeal activity of methanol extract of Santalum album L. in mice and gastrointestinal effect on the contraction of isolated jejunum in rats. J. Ethnopharmacol. 2014, 154, 704-710. [CrossRef]

9. Leonti, M.; Bellot, S.; Zucca, P.; Rescigno, A. Astringent drugs for bleedings and diarrhoea: The history of Cynomorium coccineum (Maltese mushroom). J. Ethnopharmacol. 2020, 249, 112368. [CrossRef] 
10. Njume, C.; Goduka, N.O. Treatment of diarrhoea in rural African communities: An overview of measures to maximise the medicinal potentials of indigenous plants. Int. J. Environ. Res. Public Health 2012, 9, 3911-3933. [CrossRef]

11. Hutching, A. Zulu Medicinal Plants: An Inventory; University of Natal Press: Pietermaritzburg, South Africa, 1996.

12. Van Vuuren, S.; Nkwanyana, M.N.; De Wet, H. Antimicrobial evaluation of plants used for the treatment of diarrhoea in a rural community in northern Maputaland, KwaZulu-Natal, South Africa. BMC Complement. Altern. Med. 2015, 15, 53. [CrossRef]

13. Mathabe, M.; Nikolova, R.; Lall, N.; Nyazema, N. Antibacterial activities of medicinal plants used for the treatment of diarrhoea in Limpopo Province, South Africa. J. Ethnopharmacol. 2006, 105, 286-293. [CrossRef] [PubMed]

14. Coetzee, J.H.; Littlejohn, G.M. Protea: A floricultural crop from the Cape Floristic Kingdom. Hortic. Rev. 2010, 5, 1-48.

15. Strugnell, A.M. Endemics of Mt. Mulanje. The endemic spermatophytes of Mt. Mulanje, Malawi. Sy. Geogr. Plants 2002, 72, 11-26.

16. Bamford, M.; Neumann, F.; Pereira, L.; Scott, L.; Dirks, P.; Berger, L. Botanical remains from a coprolite from the Pleistocene hominin site of Malapa, Sterkfontein Valley, South Africa. S. Afr. J. Bot. 2010, 45, 23-28.

17. Du Preez, P.; Venter, H. The phytosociology of the woody vegetation in the southern part of the Vredefort Dome Area. Part II: Communities of the hills. S. Afr. J. Bot. 1990, 56, 637-644. [CrossRef]

18. Paterson-Jones, C. Protea Family in Southern Africa; Struik Publishers (Pty) Ltd.: Cape Town, South Africa, 2000.

19. Paterson-Jones, C. Protea; Struik Publishers (Pty) Ltd.: Cape Town, South Africa, 2007.

20. Raimondo, D.; Staden, L.V.; Foden, W.; Victor, J.E.; Helme, N.A.; Turner, R.C.; Kamundi, D.A.; Manyama, P.A. Red List of South African Plants; South African National Biodiversity Institute: Pretoria, South Africa, 2009.

21. Zukulu, S. Medicinal and Charm Plants of Pondoland; South African National Biodiversity Institute (SANBI): Cape Town, South Africa, 2012.

22. Van Wyk, B.-E.; Gericke, N. People's Plants: A Guide to Useful Plants of Southern Africa; Briza Publications: Pretoria, South Africa, 2000.

23. Semenya, S.S.; Potgieter, M.J.; Erasmus, L.J.C. Exotic and indigenous problem plants species used by the Bapedi, to treat sexually transmitted infections in Limpopo Province, South Africa. Afr. Health Sci. 2013, 13, 320-326. [CrossRef]

24. Kuete, V. Potential of Cameroonian plants and derived products against microbial infections: A review. Planta Med. 2010, 76, 1479-1491. [CrossRef]

25. Eloff, J.N. A Sensitive and quick microplate method to determine the minimal inhibitory concentration of plant extracts for bacteria. Planta Medica 1998, 64, 711-713. [CrossRef]

26. Cariello, N.F.; Piegorsch, W.W. The Ames test: The two-fold rule revisited. Mutat. Res. Gen. Toxicol. Environ. 1996, 369, 23-31. [CrossRef]

27. Jäger, A.; Eloff, J. Evaluation of antibacterial activity of traditionally prepared South African remedies for infections. S. Afr. J. Bot. 2003, 69, 595-598. [CrossRef]

28. Elisha, I.L.; Botha, F.; Madikizela, B.; McGaw, L.J.; Eloff, J.N. Acetone leaf extracts of some South African trees with high activity against Escherichia coli also have good antimycobacterial activity and selectivity index. BMC Complement. Altern. Med. 2017, 17, 327. [CrossRef] [PubMed]

29. Kotze, M.; Eloff, J.; Houghton, P. Extraction of antibacterial compounds from Combretum microphyllum (Combretaceae). S. Afr. J. Bot. 2002, 68, 62-67. [CrossRef]

30. Eloff, J.N. Avoiding pitfalls in determining antimicrobial activity of plant extracts and publishing the results. BMC Complement. Altern. Med. 2019, 19, 106. [CrossRef] [PubMed]

31. Motlhatlego, K.; Njoya, E.M.; Abdalla, M.; Eloff, J.; McGaw, L.J. The potential use of leaf extracts of two Newtonia (Fabaceae) species to treat diarrhoea. S. Afr. J. Bot. 2018, 116, 25-33. [CrossRef]

32. Semenya, S.S.; Potgieter, M.J. Medicinal plants cultivated in Bapedi traditional healers homegardens, Limpopo Province, South Africa. Afr. J. Tradit. Complement. Altern. Med. 2014, 11, 126-132. [CrossRef] [PubMed]

33. Borges, A.; Ferreira, C.; Saavedra, M.J.; Simões, M. Antibacterial activity and mode of action of ferulic and gallic acids against pathogenic bacteria. Microb. Drug Resist. 2013, 19, 256-265. [CrossRef] [PubMed]

34. Lou, Z.; Wang, H.; Zhu, S.; Ma, C.; Wang, Z. Antibacterial activity and mechanism of action of chlorogenic acid. J. Food Sci. 2011, 76, 398-403. [CrossRef] [PubMed] 
35. Lou, Z.; Wang, H.; Rao, S.; Sun, J.; Ma, C.; Li, J. p-Coumaric acid kills bacteria through dual damage mechanisms. Food Control. 2012, 25, 550-554. [CrossRef]

36. Hassan, G.S.; El-Emam, A.A.; Gad, L.M.; Barghash, A.E.M. Synthesis, antimicrobial and antiviral testing of some new 1-adamantyl analogues. Saudi Pharm. J. 2010, 18, 123-128. [CrossRef]

37. Manchand, P.S.; Cerruti, R.L.; Martin, J.A.; Hill, C.H.; Merrett, J.H.; Keech, E.; Belshe, R.B.; Connell, E.V.; Sim, I.S. Synthesis and antiviral activity of metabolites of rimantadine. J. Med. Chem. 1990, 33, 1992-1995. [CrossRef]

38. El-Emam, A.A.; Al-Deeb, O.A.; Al-Omar, M.A.; Lehmann, J. Synthesis, antimicrobial, and anti-HIV-1 activity of certain 5-(1-adamantyl)-2-substituted thio-1,3,4-oxadiazoles and 5-(1-adamantyl)-3-substituted aminomethyl-1,3,4-oxadiazoline-2-thiones. Bioorganic Med. Chem. 2004, 12, 5107-5113. [CrossRef] [PubMed]

39. Makarova, N.V.; Boreko, E.I.; Moiseev, I.K.; Pavlova, N.I.; Nikolaeva, S.N.; Zemtsova, M.N.; Vladyko, G.V. Antiviral activity of adamantane-containing heterocycles. Pharm. Chem. J. 2002, 36, 3-6. [CrossRef]

40. Kritsanida, M.; Mouroutsou, A.; Marakos, P.; Pouli, N.; Papakonstantinou-Garoufalias, S.; Pannecouque, C.; Witvrouw, M.; De Clercq, E. Synthesis and antiviral activity evaluation of some new 6-substituted 3-(1-adamantyl)-1,2,4-triazolo[3,4-b][1,3,4]thiadiazoles. II Farmaco 2002, 57, 253-257. [CrossRef]

41. Kochetkov, N.; Sviridov, A.; Ermolenko, M.; Yashunsky, D.; Borodkin, V. Stereo-controlled synthesis of erythronolides A and B from 1, 6-anhydro- $\beta$-D-glucopyranose (levoglucosan). Skeleton assembly in (C9-C13)+(C7-C8)+(C1-C6) sequence. Tetrahedron 1989, 45, 5109-5136. [CrossRef]

42. Sviridov, A.F.; Ermolenko, M.S.; Yashunskii, D.V.; Borodkin, V.S.; Kochetkov, N.K. Synthesis of macrolide antibiotics. Synthesis of erythronolide A. Bull. Acad. Sci. USSR Div. Chem. Sci. 1990, 39, 179-183. [CrossRef]

43. Koay, Y.C.; Wong, K.C.; Osman, H.; Eldeen, I.; Asmawi, M.Z. Chemical constituents and biological activities of Strobilanthes crispus L. Rec. Nat. Prod. 2013, 7, 59.

44. Murugan, K.; Iyer, V.V. Antioxidant activity and Gas Chromatographic-Mass Spectrometric analysis of extracts of the marine algae, Caulerpa peltata and Padina gymnospora. Indian J. Pharm. Sci. 2015, 76, 548-552.

45. Ravichandiran, M.; Thiripurasalini, S.; Ravitchandirane, V.; Gopalane, S.; Stella, C. Chemical constituents and anti-tuberculosis activity of ink extracts of cuttlefish, Sepiella inermis. J. Coast Life Med. 2013, 1, 253-257.

46. Sharma, A.; Menghani, E. Antibiotic potentials and isolation of metabolomes from microorganisms of mesophilic soil of Rajasthan, India. Afr. J. Microbiol. Res. 2017, 11, 335-344.

47. Al-Abd, N.M.; Nor, Z.M.; Mansor, M.; Azhar, F.; Hasan, M.S.; Kassim, M. Antioxidant, antibacterial activity, and phytochemical characterization of Melaleuca cajuputi extract. BMC Complement. Altern. Med. 2015, 15, 385. [CrossRef]

48. Sultana, N.; Akhter, M.; Khan, R.A.; Afza, N.; Tareen, R.B.; Malik, A. Nematicidal natural products from the aerial parts of Buddleja crispa. Nat. Prod. Res. 2010, 24, 783-788. [CrossRef] [PubMed]

49. Unnikrishnan, P.; Suthindhiran, K.; Jayasri, M. Inhibitory potential of Turbinaria ornata against key metabolic enzymes linked to diabetes. Biomed. Res. Int. 2014, 2014, 783895. [CrossRef] [PubMed]

50. Yasa, N.; Masoumi, F.; Rouhani, R.; Haji, A. Chemical composition and antioxidant activity of the extract and essential oil of Rosa damascena from Iran, population of Guilan. Daru 2009, 17, 175-180.

51. Alagammal, M.; Tresina, P.; Mohan, V. GC-MS determination of bioactive components of Polygala javana DC. Int. J. Curr. Pharm. Res. 2012, 4, 42-44.

52. Mao, C.H.; Wang, Q.M.; Huang, R.Q.; Bi, F.C.; Chen, L.; Liu, Y.X.; Shang, J. Synthesis and insecticidal evaluation of novel N-oxalyl derivatives of tebufenozide. J. Agric. Food Chem. 2004, 52, 6737-6741. [CrossRef]

53. Abubaker, M.A.; Wandruszka, R.V. Determination of phenolic herbicides in soil by peroxyoxalate chemiluminescence. Anal. Lett. 1991, 24, 93-102. [CrossRef]

54. Taylor, J.L.; Elgorashi, E.E.; Maes, A.; Van Gorp, U.; De Kimpe, N.; Van Staden, J.; Verschaeve, L. Investigating the safety of plants used in South African traditional medicine: Testing for genotoxicity in the micronucleus and alkaline comet assays. Environ. Mol. Mutagen. 2003, 42, 144-154. [CrossRef]

55. Ndhlala, A.; Anthonissen, R.; Stafford, G.; Finnie, J.F.; Verschaeve, L.; Van Staden, J. In vitro cytotoxic and mutagenic evaluation of thirteen commercial herbal mixtures sold in KwaZulu-Natal, South Africa. S. Afr. J. Bot. 2010, 76, 132-138. [CrossRef]

56. Verschaeve, L.; Kestens, V.; Taylor, J.L.S.; Elgorashi, E.E.; Maes, A.; Van Puyvelde, L.; De Kimpe, N.; Van Staden, J. Investigation of the antimutagenic effects of selected South African medicinal plant extracts. Toxicol. Vitr. 2004, 18, 29-35. [CrossRef] 
57. Vambe, M.; Aremu, A.; Chukwujekwu, J.; Finnie, J.F.; Van Staden, J. Antibacterial screening, synergy studies and phenolic content of seven South African medicinal plants against drug-sensitive and -resistant microbial strains. S. Afr. J. Bot. 2018, 114, 250-259. [CrossRef]

58. Gruz, J.; Novák, O.; Strnad, M. Rapid analysis of phenolic acids in beverages by UPLC-MS/MS. Food Chem. 2008, 111, 789-794. [CrossRef]

59. Elgorashi, E.E.; Taylor, J.L.S.; Maes, A.; Van Staden, J.; De Kimpe, N.; Verschaeve, L. Screening of medicinal plants used in South African traditional medicine for genotoxic effects. Toxicol. Lett. 2003, 143, 195-207. [CrossRef]

60. Maron, D.M.; Ames, B.N. Revised methods for the Salmonella mutagenicity test. Mutat. Res. 1983, 113, $173-215$. [CrossRef]

(C) 2020 by the authors. Licensee MDPI, Basel, Switzerland. This article is an open access article distributed under the terms and conditions of the Creative Commons Attribution (CC BY) license (http://creativecommons.org/licenses/by/4.0/). 